\title{
MEASUREMENT OF THE PERFORMANCE AND ACCOUNTABILITY OF ZAKĀH ORGANIZATIONS IN YOGYAKARTA
}

\author{
Wirawan Hardinto, Sigit Handoyo, Mahdalena Toha \\ Universitas Islam Indonesia \\ Email : sigit.handoyo@uii.ac.id
}

\section{Abstract}

This study aimed to investigate the influence of spirituality, internal control, and organization commitment toward Zakāh organization performance and internal control toward accountability in Zakäh organizations. The population of the study is the staff of BAZ and LAZ in Province of DI Yogyakarta who has a minimum position at the middle manager. There are 16 of 28 BAZ and LAZ in Province of DI Yogyakarta which participated in this research. The number of the sample was 63 respondents. All data of the respective measurement items are tested with reliability and validity test based on Alpha Cronbach to the internal consistency by using SPSS program version 15 and to analyze the structural equation model by using PLS (Partial Least Square). The model of the relationship between five variables is shown that internal control has positive effects on accountability. Accountability has a positive relation with Zakäh organization performance. Internal control has a positive relation with Zakāh organization performance. Meanwhile, organization commitment does not influence on Zakāh organization performance. Spirituality has a positive relation to Zakāh organization performance.

Keywords: internal control, spirituality, organization commitment, accountability, Zakāh organizations performance.

\section{Abstrak}

Penelitian ini bertujuan mengkaji pengaruh spiritualitas, pengendalian internal, dan komitmen organisasi terhadap kinerja organisasi zakat dan pengendalian internal terhadap akuntabilitas dalam organisasi zakat. Populasi penelitian ini adalah staf BAZ dan LAZ di Provinsi DI Yogyakarta yang memiliki posisi minimum manajer. 
Ada 16 dari 28 BAZ dan LAZ di Provinsi DI Yogyakarta yang berpartisipasi dalam penelitian ini. Jumlah sampel adalah 63 responden. Semua data dari masing-masing item pengukuran diuji dengan uji reliabilitas dan validitas berdasarkan Alpha Cronbach untuk konsistensi internal dengan menggunakan program SPSS versi 15 dan untuk menganalisis model persamaan struktural dengan menggunakan PLS (Partial Least Square). Model hubungan antara lima variabel ditunjukkan bahwa pengendalian internal berpengaruh positif terhadap akuntabilitas. Akuntabilitas memiliki hubungan positif dengan kinerja organisasi zakat. Kontrol internal memiliki hubungan positif dengan kinerja organisasi zakat. Sementara itu, komitmen organisasi tidak mempengaruhi kinerja organisasi zakat. Spiritualitas memiliki hubungan positif dengan kinerja organisasi zakat.

Kata Kunci: pengendalian internal, spiritualitas, komitmen organisasi, akuntabilitas, kinerja organisasi zakat.

\section{Introduction}

Zakāh is the third of the five basic pillars of Islamic faith. Furthermore, according to Kahf, Zakāh is also a part of a social system of Islam as the social goals of Zakāh indicate that Allah has given the poor rights in the wealth of the rich. ${ }^{1}$ Thus, Zakāh acts as a mechanism for the distribution of wealth, which helps to close the gap between the poor and the rich. Indonesia is well-known as a country with the biggest Muslim population, so Zakāh is significant and needs big-attention in improving the wealth of citizen. It has proven by the development of Zakāh Management Organization (Organisasi Pengelola ZakatOPZ) in Indonesia increase rapidly. According to data by Zakāh Organization Forum (Forum Organisasi Zakat-FOZ)², nowadays there are more than 300 Zakāh Amil Institution (Lembaga Amil Zakat-LAZ) in Indonesia and even, Saidi said that Zakāh Amil Council (Badan Amil Zakat-BAZ) which established by government from central government to regional/local government has reached more than 30.000 organizations. ${ }^{3}$ Through the projection of Public Interest Research and Advocacy Center (PIRAC), ${ }^{4}$ there are potentials Zakah,

\footnotetext{
${ }^{1}$ M. Kahf, "Potential Effects of Zakah on Government Budget", IIUM Journal of Economics and Management, Vol.5, No. 1, 1997, pp. 67-85.

${ }_{2}$ Zakat Forum, or abbreviated as FOZ, is an association of Zakat management institutions that functions as a forum for gathering the Zakat Amil Council (BAZ) and the Zakat Amil Institution (LAZ) throughout Indonesia and which was established on Friday, September 19, 1997.

${ }^{3}$ Zaim Saidi et.al. Filantropi menuju CSR: Potret Kedermawanan Sosial Perusahaan di Indonesia (Jakarta: Piramedia, Ford Foundation dan PIRAC, 2003).

${ }^{4}$ PIRAC is a non-profit and independent resource organization that provides services in the form of research, training, advocacy and information dissemination in the field of philanthropy and strengthening civil society organizations in Indonesia with funding support from donor agencies, community donations, and independent businesses.
} 
Infaq, Shadaqah, and Waqaf (ZISWAF) fund in Indonesia that has reached 11.5 trillion rupiahs, thus Zakäh is able to be one big income sources in solving the poverty problems in Indonesia. In Province of DI Yogyakarta, Kholis et al stated that philanthropy funds which are categorized as Zakāh are predicted more than 600 billion every year. $^{5}$

OPZ as one of institutions that has significant role in public will deal with the improving of awareness and controlling the citizen, so it has a problem regarding the performance measurement which is measured to success or even failure implementation such as the problems of managerial, manage the programs, and efforts to establish transparency and public accountability. Besides the quality management standard, OPZ is inevitable regarding the issue of Amil Zakāh. Thus, the problem of quality management and Amil certification will lead to two main inseparable issues, they are in accountability and performance measurement for zakat organization. Yet in fact, according to a research conducted by Sadjiarto found that accountability of public sector organization in Indonesia only emphasized on the management of public sector side. Whereas, the annual report is not enough as a form of accountability of public. ${ }^{6}$

The role of OPZ as one of a nonprofit organization is not only limited on socialization and collector of zakat funds. Moreover, the trust of the Ummah and Allah commands must run as good as possible to ensure the distribution as well. This study seeks to investigate a form of accountability and performance measurement of Zakāh organization in Indonesia, particularly for BAZ and LAZ, which both have not had the fixed rule to measure the performance of the organization.

\section{Research Method}

The population as a whole unit of analysis is OPZ consisting of BAZ and LAZ incorporated community organizations or foundations that are in the Republic of Indonesia. The data obtained from the directory forum OPZ Zakat (FOZ) as associate charity management organization. The data was taken from the Ministry of Religious Affairs sites that informed the total of active BAZ \& LAZ in Province DI Yogyakarta, which is 28 Zakäh organizations. The samples in this study are 63 respondents who work in BAZ and LAZ in the province of DI Yogyakarta.

${ }^{5}$ Kholis et al, "Potret Filantropi Islam di Provinsi Daerah Istimewa Yogyakarta", La_Riba. Vol. 7, No. 1, 2013, pp. 61-84.

${ }^{6}$ A. Sadjiarto, "Akuntabilitas \& Pengukuran Kinerja Pemerintahan", Jurnal Akuntansi dan Keuangan, Vol. 2, No. 2, 2000, pp. 138-150. 
The technique in selecting the sample of this research use non-probability sampling technique in particular types of purposive sampling. It is based on several criteria that should be met in taking required sample, they are (1) For LAZ, its form of foundations or community organizations; (2) For BAZ, it operates in provinces or districts that already had local regulations (regulations) or regional head regulation (laws or regulations governor regent/mayor) of the charity; (3) OPZ that has been in operation at least 1 years; and (4) Min. Operating Manager/ Coordinator of Division.

The dependent variable is performance measurement which is the instrument was initiated by Indonesia Magnificence of Zakat (IMZ) as a nonprofit organization that performs measurement of performance in the form of twigs on Zakāh Management Organization, particularly in Zakāh Institutions in Indonesia. The components that form the basis of assessment by IMZ refers to the four components, namely the performance of Sharia Compliance, Legal, and Institutional, Financial Performance and Legitimacy of Social, Economic Performance, and Social Performance Politics. The number of all criteria consists of 20 questions.

Independent variables that will be examined are spirituality, internal control and organization commitment. Spirituality measurement is constructed according to Karakas regarding perspective or dimension of spirituality and its association with organization performance. It consisted of 3 aspects spirituality enhancing employee well-being and quality of life. Spirituality gives a sense of purpose and meaning of work and, gives employee a sense of spirituality and that society are interconnected. So, this variable is measured by 14 questions. Instrument of internal control measurement is initiated by IAI (Ikatan Akuntan Indonesia) explanation. Internal control's components consist of five aspects, they are: control environment which has six indicators; risk assessments which has three indicators; control activity which has four indicators; information and communication which have two indicators; and observation that has only one indicator. Thus, this variable is measured by 31 indicators or questions. Organization commitment in this study was measured by a construct developed by Allen and Meyer using three dimensions, they are: (1) affective commitment, (2) continuance commitment, and (3) normative commitment, the total of questions are 18 items. Accountability concept explained by Peter as cited in Hamidi consisted of three types, they are: (1) Financial accountability, (2) 
Administrative accountability, (3) Public policy accountability. ${ }^{7}$ Through this instrument, each aspect has some criteria such as: financial accountability aspects consist of financial report presentation and financial control assessment, administrative accountability aspects consists of the fulfillment of ethics standard and values and punctual assessments, and public policy accountability aspect, consist of financial report presentation and financial control assessment. Thus, this variable is measured by eight questions.

\section{Organization Performance}

The performance is a pattern of actions taken to achieve the objectives as measured by basing on a comparison of the various standards. Performance is an overview of the level of achievement of the implementation of a program or activity in achieving organization objectives which are stated in the strategic planning of the organization. ${ }^{8}$ Thus, performance measurement is able to determine the level of operational effectiveness within the organization.

According to Meutia, the performance measurement is basically comparing actual performance with targets set. In general, the existence of any organization tends to do a performance that is expected to help answer how big accountability is. Performance can be measured by several indicators and can be classified into two categories, they are (1) Non-financial performance measurement and (2) financial performance measurement. Both measurements were mostly developed by Balance Score Card model. ${ }^{9}$

Meanwhile, Mutharika explained that accountability consists of 3 types, such as (1) Financial accountability, (2) Administrative accountability, and (3) Public policy accountability. ${ }^{10}$ Thus, public accountability is principles that grant every governance activities that can be responsible by the perpetrator to the parties who affected by the application of the policy. Thus, public accountability is principles that grant every governance activities that can be responsible by the perpetrator to the parties who affected by the application of the policy. ${ }^{11}$

${ }^{7}$ Nurhasan Hamidi, "Analisis Akuntabilitas Publik dan Kinerja Organisasi Pengelola Zakat Berdasarkan Aspek Pengendalian Intern dan Budaya Organisasi: Survei pada Organisasi Pengelola Zakat di Indonesia”. Unpublished Thesis. Gadjah Mada Univeristy, Yogyakarta, 2009.

${ }^{8}$ Mahsun, Akuntansi Sektor Publik (Yogyakarta: Fakultas Ekonomi UGM, 2006).

${ }^{9}$ L. Meutia, "Analisis Pengukuran Kinerja Organisasi Pengelola Zakat berdasarkan Klasifikasinya: Studi Kasus Tiga Lembaga Amil Zakat Nasional. Unpublished thesis, Universitas Indonesia, Jakarta, 2002.

${ }^{10}$ A. Peter Mutharika, "Accountability for Political Abuses in Pre-Democratic Malawi. The Primary of Truth", Third World Legal Studies, Vol. 16, No. 1, 2003, pp. 203 -218.

${ }^{11}$ L.P.L. Krina, Indikator dan Alat Ukur Prinsip Akuntabilitas, Transparansi dan Partisipasi, (Jakarta: Sekretariat Good Governance Badan Perencanaan Pembangunan Nasional, 2003). 
Furthermore, Porter defined organization commitment as the relative strength of the individual to an organization and involvement in a particular organization, which characterized by three psychological factors: (1) strong desire to remain a member of particular organization, (2) willingness to bend over backwards for the sake of the organization and (3) a definite belief and acceptance of the values and goals of the organization. ${ }^{12}$ Allen and Meyer proposed three forms organization commitment, they are:

1. Affective commitment, which is an emotional attachment, identification, and involvement in an organization. In this case, the individual settled in an organization because of their own desires.

2. Continuants commitment, i.e. individual commitment which is based on the consideration of what to be sacrificed when leaving the organization. In this case, the individual decides to settle on an organization because it is a need.

3. Normative commitment, which is an individual's belief about the responsibility of the organization. Individuals stay in an organization because he/she is obliged to be loyal to the organization. ${ }^{13}$

Karakas tried to find perspective or dimension of spirituality and its association with organization performance. Approximately 140 reviewed literatures was stated there are three different perspectives on how spirituality members introduced a benefit to employees and supported organization performance. ${ }^{14}$ These include: Spirituality enhances employee well-being and quality of life, Spirituality gives a sense of purpose and meaning in work, and Gives employees a sense of spirituality and society that are interconnected.

Figure 1.

Three Perspectives of Spirituality and Performance

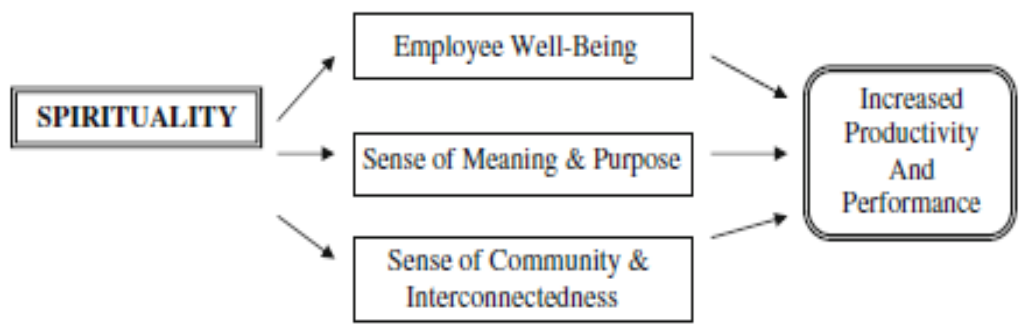

\footnotetext{
${ }^{12}$ T. Porter, Measuring Performance in Public \& Non-Profit Organizations. (Sans Fransisco: Jossey Bass Publisher, 2003).

${ }^{13}$ N.J. Allen \& J.P. Meyer, “The Measurement and Antecedents of Affective, Continuance, and Normative Commitment”, Military Psychology, Vol. 5, No. 1, 1990, pp. 237-253.

${ }^{14}$ F. Karakas, "Spirituality and Performance in Organizations: A Literature Review", Journal of Business Ethics, Vol. 94, No. 1, 2010, pp. 89-106.
} 
The first perspective is the welfare of employees. This perspective is taken from the perspective of human resources. This includes the level of the individual against the positive effects of spirituality, concerning the welfare, morale, and commitment. This perspective has a core principle that incorporates spirituality in the work will improve the welfare of employees by increasing commitment, morale, and productivity, and instead will reduce stress, fatigue, and a crazy work in the world of work. In the second perspective, the purpose and meaning in work, seen from the perspective that the people who work it are in search of purpose and meaning of life. When spirituality is high, then the search for purpose and meaning will be more readily available, so it can reduce emotion when working. In the third perspective, namely the perspective of interpersonal and community, that is when the person has spirituality in the work, then this will increase the sense of loyalty are interconnected with one another, and a sense of ownership in the organization.

The Influence of Internal Control toward Accountability and Zakāh Organization Performance

Prasetyono and Kompyurini revealed that the organization culture, organization commitment, and public accountability simultaneously give positive and significant effect on the performance of the Regional Hospital (RSD) in the strong category. Partially, organization culture influence organization commitment in low category positively and significantly on the performance of RSD. However, the positive effect of public accountability is in the low category and no significant effect on the performance of RSD. Organization culture influence performance with low impact. Whereas, internal control has a positive impact on the application of the principles of Good Corporate Governance (GCG) at a moderate level. Commitment and internal control affect the principles of good corporate governance simultaneously at a sufficient level. ${ }^{15}$

From above the explanation, two hypotheses is proposed:

$\mathrm{H}_{1}$ : There is a positive effect of Internal Control and Accountability.

$\mathrm{H}_{3}$ : There is a positive effect between Internal Control to Zakāh organization performance.

The Relationship of Accountability and Organization performance

${ }^{15}$ Prasetyono \& Kompyuruni, "Analisis Kinerja RSD Berdasarkan Budaya Organisasi, Komitemen Organisasi, Akuntabilitas Publik (Survey pada RSD di JATIM)”, Unpublished Doctoral Dissertation, Universitas Airlangga, Surabaya, 2008. 
Research conducted by Cavaluzzi and Ittner found a number of organization factors affect the implementation of performance measurement systems. Organization factors such as management commitment to use performance information, decision-making authority, and training performance measurement techniques provide a positive and significant influence on the use and development of performance measurement systems. In addition, the measurement of performance is also presented positively associated with accountability through the use of performance information for various purposes. All the variables in the study both technical factors and organization factors interact to influence the implementation of the measurement system. ${ }^{16}$ Based on the above explanation, the researcher proposes the third hypothesis:

$\mathrm{H}_{2}$ : There is a positive association between accountability and Zakäh organization performance.

The Influence of Organization Commitment toward Zakāh Organization Performance

Meigitania's research about the influence of organizational commitment and organization culture toward the performance of the employee in PT Pupuk Iskandar Muda, showed that organization commitment variable simultaneously affected the employee's performance. ${ }^{17}$ Meanwhile, if tested separately (each variable), it will show that organization culture is not significant toward the performance; on the contrary, the result of organizational commitment is significant and positively influence toward performance. According to an analysis of the influence of commitment aspects toward employee's performance in PT Iskandar Muda, the most influential aspects in an employee's performance is a normative aspect. Thus, the affective, continuance, and normative aspects simultaneously influence the performance.

It is also supported by research conducted by Ivano which stated that organization commitment has a positive effect on the performance of public organizations. ${ }^{18}$ They suggested that a strong organizational commitment will encourage individuals to try harder to achieve organization goals. Thus, a strong commitment makes individuals more concerned with the organization

${ }^{16}$ Kens Cavaluzzi and C. Ittner, "Implementing Performance Measurement Innovations: Evidence from Government", Accounting, Organisation \& Society, vol. 29, no. 3-4, 2003, pp. 243267.

${ }^{17}$ Meigitania, "Pengaruh Komitmen dan Budaya Organisasi terhadap Kinerja Karyawan pada PT. Pupuk Iskandar Muda. Unpublished Thesis. Universitas Gadjah Mada, Yogyakarta, 2009.

${ }^{18}$ Y. Ivano, "Pengaruh Motivasi dan Komitmen Organisasi terhadap Kinerja Pegawai (Studi pada Kantor Pertanahan BPN Kota Semarang). Unpublished Thesis, Universitas Diponegoro, Semarang, 2009. 
of personal interests. So, between organizational commitment and performance in which there is a positive effect of good performance is certainly motivated by a strong commitment. Poor organization commitment does not produce high performance. Thus, the higher degree of organization commitment the higher the performance it achieves as well. Therefore, the hypothesis is:

$\mathrm{H}_{4}$ : Organization commitment has a positive association with organization performance.

The Influence of Spirituality toward Zakāh Organization Performance

From literature study conducted by Karakas showed that all the research supports and shows how productivity and performance increases as a result of deeper meaning at work; as well as how spirituality at work can provide employees a sense of meaning and purpose. The common pattern in all these work seems to be the fact that workers want to be recognized for who they are; as a person with spirit, heart, soul, passions, hopes, talents, aspirations, families, private lives, emotions, ups and downs, and diverse perspectives on matters. Therefore, the hypothesis is:

$\mathrm{H}_{5}$ : Spirituality is associated positively with zakah organization performance.

Figure 2.

Research Model

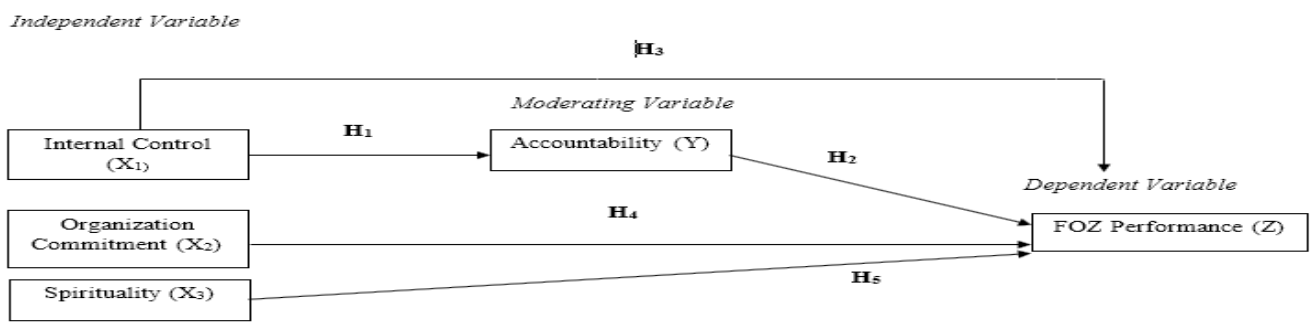

\section{Results and Discussion}

The validity test result, it showed that the result of validity has not fulfilled the convergent validity. In order to appear the valid item, all invalid items should be eliminated. Then, the result showed the valid item although, the items of each variable will be lessened. The result after step 2 , all indicators have been valid which is obtained after eliminating invalid items.

Composite reliability aims to explain the reliability testing of data construction. If, a certain construct has a composite reliability value, which is 
over 0.70 . Thus, the construct revealed as reliable. The following table 2 are the results of research obtained from the data tabulation by PLS software.

Table 2: Composite Reliability

\begin{tabular}{|c|c|}
\hline Variables & Composite Reliability \\
\hline Accountability & 0.898423 \\
\hline FOZ_Performance & 0.868426 \\
\hline Internal_C & 0.896216 \\
\hline Kom_Org & 0.865189 \\
\hline Spirituality & 0.892569 \\
\hline
\end{tabular}

Sources: Primary data processed, 2014

According to table 2, it can be summed all questions (final) have been reliable because Composite Reliability value of all variables is over 0.7. Thus, the research model has fulfilled the appropriateness model in terms of data reliability.

\section{Hypothesis Testing}

The result of data tabulation by using PLS software is showed in table 4.17 as follows:

Table 3: Results of Inner Weights

\begin{tabular}{|c|c|c|c|c|c|}
\hline & $\begin{array}{l}\text { Original } \\
\text { Sample } \\
\text { (O) }\end{array}$ & $\begin{array}{c}\text { Sample } \\
\text { Mean } \\
\text { (M) }\end{array}$ & $\begin{array}{l}\text { Standard } \\
\text { Deviation } \\
(\text { STDEV })\end{array}$ & $\begin{array}{c}\text { Standard } \\
\text { Error } \\
\text { (STERR) }\end{array}$ & $\begin{array}{c}\text { T Statistics } \\
(\mid \mathrm{O} / \text { STERR } \mid)\end{array}$ \\
\hline Accountability-> FOZ_Performance & 0.593233 & 0.580668 & 0.081396 & 0.081396 & 7.288252 \\
\hline Internal_C -> Accountability & 0.615463 & 0.631206 & 0.055927 & 0.055927 & 11.004679 \\
\hline Internal_C -> FOZ_Performance & 0.419977 & 0.415079 & 0.100699 & 0.100699 & 4.170606 \\
\hline Kom_Org -> FOZ_Performance & 0.119473 & 0.139107 & 0.074911 & 0.074911 & 1.594853 \\
\hline Spirituality -> FOZ_Performance & 0.220240 & 0.223177 & 0.078129 & 0.078129 & 2.818926 \\
\hline \multicolumn{6}{|c|}{ Sources: Primary data processed, 2014} \\
\hline $\begin{array}{l}\mathrm{Y}=0.615463 \mathrm{X}_{1} \\
\mathrm{Z}=0.419977 \mathrm{X}_{1}+0.1 \\
\text { Details: }\end{array}$ & $119473 \mathrm{X}$ & +0.22 .24 & $40 \mathrm{X}_{3}+0.5$ & $93233 \mathrm{Y}$ & \\
\hline \multicolumn{6}{|c|}{$=$ Internal Control } \\
\hline \multicolumn{6}{|c|}{$=$ Organization Commitment } \\
\hline \multicolumn{6}{|c|}{$=$ Spirituality } \\
\hline$=$ Accountab & \multicolumn{5}{|c|}{$=$ Accountability } \\
\hline \multicolumn{6}{|c|}{$=$ Zakah Organization Performance } \\
\hline
\end{tabular}

The result can be interpreted by conducting $t$-statistic test comparing between the results of $\mathrm{t}$-statistic to $\mathrm{t}$-table. Moreover, $\mathrm{t}$-table determine the significance on value 0.05 where $t$-statistic $>$ (more than) $t$-table by 1.64 . Value of t-statistic calculated by using formula as follow: 


$$
\mathrm{T}=\frac{\text { Koefisien Original Sampel }(\mathrm{O})}{\text { Standard Error }(\text { STERR })}
$$

The relationship between Internal Control and Accountability

$$
\mathrm{T}=\frac{0.615463}{0.055927}=1.00476
$$

Through the result of the inner model revealed that $\mathrm{t}$-statistic is $11.004>1.64$. The result concludes the first hypothesis that stated " $H_{1}$ : There is a positive effect of internal control and accountability" is acceptable or unsuccessful rejected.

Organization commitment does not have influence significantly toward the Zakāh organization performance. These findings explained that the Zakāh organization performance is not optimal because of the low organizational commitment. But, organization commitment is not the main factor in creating the performance. It is probably because of the organizational climate and leadership style which influence the organizational commitment. In line with the Erben and Guneser findings that found that organization climate consist of wisdom will give positive influence to commitment organization whereas, the organization climate which consists of egoism will give negative influence and impair the organization performance. ${ }^{19}$

The relationship between Accountability and Zakāh Organization Performance

$$
\mathrm{T}=\frac{0.593233}{0.081396}=7.288233
$$

Through the result of the inner model, it revealed that $\mathrm{t}$-statistic is $1.64<7.288233$. The result concluded the second hypothesis that stated " $\mathrm{H}_{2}$ : There is a positive association between accountability and the Zakāh organization performance" is acceptable or unsuccessful rejected.

Accountability has significant influence toward Zakäh organization performance. This condition showed that higher accountability will encourage Zakāh organization performance. Besides, according to Peter, the public accountability indicates Zakāh organization has optimized the inputs of accountability that consists of (1) Financial accountability, (2) Administrative accountability, (3) Public policy accountability.

${ }^{19}$ G.S. Erben, and A.B. Guneser, "The Relationship Between Paternalistic Leadership and Organizational Commitment: Investigating the Role of Climate Regarding Ethics", Journal of Business Ethics, Vol. 82, No. 4, 2008, pp. 955-968. 
The relationship between Internal Control and Zakāh Organization Performance

$$
\mathrm{T}=\frac{0.419977}{0.100699}=4.170617
$$

Through the result of the inner model, it revealed that t-statistic is $1.64<4.170617$. The result concluded this hypothesis that stated " $\mathrm{H}_{3}$ : There is a positive effect between internal control to Zakāh organization performance" is acceptable or unsuccessful rejected.

Internal control has significant influence toward the Zakäh organization performance at a high level. This condition showed that the higher the internal control will encourage organization performance. Based on the research which is conducted by Prasetyono et al it revealed that there is a positive impact on the application of the performance of Good Corporate Governance (GCG) at a moderate level. Then, from this research, it is also obtained the condition that internal control has significant influence and positive correlation toward public accountability. This means the internal control has applied properly in Zakāh organization. Thus, the higher internal control condition will encourage public accountability. This is supported by the research of Hamidi of which internal control has significant influence toward accountability at a moderate level.

The relationship between Organization Commitment and Organization Performance

$$
\mathrm{T}=\frac{0.119473}{0.074911}=1.594866
$$

Through the result of the inner model, it revealed that t-statistic is $1.594866<1.64$. It concludes the hypothesis that stated "Organization commitment has a positive association to Zakāh organization performance" is rejected.

Organization commitment does not have influence significantly toward the Zakāh organization performance. These findings explained that the Zakāh organization performance is not optimal because of the low organizational commitment. But, organization commitment is not the main factor in creating the performance. It is probably because of the organizational climate and leadership style which influence the organizational commitment. In line with the Erben et al. findings that found that organization climate consist of wisdom will give positive influence to commitment organization whereas, the organization climate which consists of egoism will give negative influence and impair the organization performance. 
The relationship between Spirituality and Zakāh Organization Performance

$$
\mathrm{T}=\frac{0.22024}{0.078129}=2.818928
$$

Through the result of the inner model, it revealed that $\mathrm{t}$-statistic is $2.818928<1.64$. So the hypothesis that stated "Spirituality is associated positively to Zakāh organization performance." is acceptable or unsuccessful rejected. Spirituality also has significant influence toward Zakāh organization performance. This indicates that higher spirituality will encourage Zakāh organization performance. Thus, spirituality aspect is significant in improving productivity as Giacalone and Jurkiewicz explained that the organizations that will encourage spirituality experiences to improve their organizational performance and profitability. ${ }^{20}$

Table 4: Results of R-Square

\begin{tabular}{ll}
\hline & R-Square \\
\hline Accountability & 0.378795 \\
\hline FOZ_Performance & 0.717143 \\
\hline Internal_C & \\
\hline Kom_Org & \\
\hline Spirituality & \\
\hline
\end{tabular}

Sources: Primary data processed, 2014

Value of $\mathrm{R}$ square for Accountability is 0.378795 . It means that accountability can be explained by internal control at $37.9 \%$. Then, the remains are $62.1 \%$ of another variable will explain the accountability. Value of $\mathrm{R}$ square for Zakäh organization performance is 0.717143 which means the internal control, organization commitment and spirituality can be explained by $71.2 \%$. In other words, the remains of $28.8 \%$ will be explained by the others.

The regression analysis found that partially variable of spirituality, accountability and internal control influence significantly toward the performance in Zakāh organization in the Province of DI Yogyakarta. This research indicates which performance will be optimal if it is supported by aspects of spirituality, accountability, and internal control. Then, the existence of good internal control will increase accountability directly.

\footnotetext{
${ }^{20}$ R.A. Giacalone and C.L. Jurkiewicz, Toward a Science Workplace Spirituality: Handbook of Workplace Spirituality and Organisational Performance, (NY: M.E. Sharpe, Amonk, 2003), pp. 3-28. The study of the influence of spirituality on the performance of employee, see for example Rosidin, "Pengembangan Spiritual Religius dan Kinerja Pegawai Pemerintah Kotamadya Jakarta Barat", Indonesian Journal of Islamic Literature and Muslim Society, Vol. 2, No. 2, 2017, pp. 207-234.
} 


\section{Conclusion}

This research aims to analyze and discuss the influence of aspects of spirituality, internal control, organization commitment and accountability toward Zakāh organization performance. The result indicates that internal control has positive effects on accountability. Accountability has a positive relation with Zakāh organization performance. Internal control has a positive relation with zakah organization performance. Meanwhile, organization commitment does not influence Zakāh organization performance. Spirituality has a positive relation to Zakāh organization performance.

On the basis of the research result and its limitation, it is recommended that for Zakāh organization management, the organization commitment aspect needs to be increased in optimizing the organization performance, because of some factors, such as the job satisfaction which is able to create the people's loyalty, attention, and involvement in the workplace. Then, internal control also should be created in order to encourage accountability and increase the Zakāh organization performance. Spirituality aspect has an important influence on zakah organization performance. Moreover, for the further researcher, the research object is necessary to be in broader scope because the Zakāh organization increases every year. Then, it is necessary to find the method in obtaining data more complete and clear. For example, by visiting the respondent directly in process of distributing and collecting the questionnaire and by interviewing directly the respondent which reflect the more truthful answer. Besides that, it is necessary to develop another variable regarding the increasing of Zakāh organization performance, such as leadership style and organization structure. 


\section{BIBLIOGRAPHY}

Allen. N.J. and Meyer J.P. "The Measurement and Antecedents of Affective, Continuance, and Normative Commitment”. Military Psychology, vol. 5, No.1. 1997.

Cavaluzzi, Kens and Ittner, C. "Implementing Performance Measurement Innovations: Evidence from Government", Accounting, Organisation \& Society, vol. 29, No 3-4. 2004.

Erben, G.S., and Guneser, A.B. "The Relationship Between Paternalistic Leadership and Organizational Commitment: Investigating the Role of Climate Regarding Ethics”, Journal of Business Ethics, Vol. 82, No.4. 2008.

Forum Organisasi Zakat. Retrieved from. https://forumzakat.org.blog. 2009.

Giacalone, R.A. and Jurkiewicz, C.L. Toward a Science Workplace Spirituality: Handbook of Workplace Spirituality and Organisational Performance, NY: M.E. Sharpe, Amonk, 2003.

Hamidi, Nurhasan. "Analisis Akuntabilitas Publik dan Kinerja Organisasi Pengelola Zakat Berdasarkan Aspek Pengendalian Intern dan Budaya Organisasi. Survei pada Organisasi Pengelola Zakat di Indonesia”. Unpublished Thesis. Universitas Gadjah Mada, Yogyakarta. 2009.

Ivano, Y. "Pengaruh Motivasi dan Komitmen Organisasi terhadap Kinerja Pegawai (Studi pada Kantor Pertanahan BPN Kota Semarang)", Unpublished Thesis, Universitas Diponegoro, Semarang, 2009.

Kahf, M. "Potential Effects of Zakah on Government Budget", IIUM Journal of Economics and Management, Vol. 5, No.1. 1997.

Karakas, F. "Spirituality and Performance in Organizations: A Literature Review", Journal of Business Ethics, Vol. 9, No.1. 2010.

Kholis, Nur et al. "Potret Filantropi Islam di Provinsi Daerah Istimewa Yogyakarta", La_Riba, Vol. 7, No.1.2013.

Krina L.P.L. Indikator Dan Alat Ukur Prinsip Akuntabilitas, Transparansi dan Partisipasi, Jakarta: Sekretariat Good Governance Badan Perencanaan Pembangunan Nasional, 2003.

Mahsun. Akuntansi Sektor Publik. Yogyakarta: Fakultas Ekonomi UGM. 2006. 
Meigitania. "Pengaruh Komitmen dan Budaya Organisasi terhadap Kinerja Karyawan pada PT. Pupuk Iskandar Muda". Unpublished Thesis. Universitas Gadjah Mada, Yogyakarta, 2009.

Meutia, L. "Analisis Pengukuran Kinerja Organisasi Pengelola Zakat berdasarkan Klasifikasinya: Studi Kasus Tiga Lembaga Amil Zakat Nasional”, Unpublished thesis, Universitas Indonesia, Jakarta, 2012.

Mutharika, A. Peter. "Accountability for Political Abuses in Pre-Democratic Malawi. The Primary of Truth", Third World Legal Studies, vol. 16, No.1. 2003.

PIRAC. Pola dan Kecenderungan Masyarakat dalam Berzakat (Hasil Survei sebelas kota di Indonesia). Jakarta: PIRAC. 2007.

Porter, T. Measuring Performance in Public \& Non-Profit Organizations. Sans Fransisco: Jossey Bass Publisher. 2003.

Prasetyono \& Kompyuruni. "Analisis Kinerja RSD Berdasarkan Budaya Organisasi, Komitemen Organisasi, Akuntabilitas Publik: Survey pada RSD di Jatim”. Unpublished Doctoral Dissertation, Universitas Airlangga, Surabaya, 2008.

Rosidin. "Pengembangan Spiritual Religius dan Kinerja Pegawai Pemerintah Kotamadya Jakarta Barat", Indonesian Journal of Islamic Literature and Muslim Society, Vol. 2, No. 2, 2017.

Sadjiarto, A. "Akuntabilitas \& Pengukuran Kinerja Pemerintahan", Jurnal Akuntansi dan Keuangan, Vol. 2, No.2. 2000.

Saidi, Zaim et al. Filantropi menuju CSR: Potret Kedermawanan Sosial Perusahaan di Indonesia. Jakarta: Piramedia-Ford Foundation-PIRAC, 2003. 